\title{
Effects of the Folk Medicinal Plant Extract Ankaferd BloodStopper on the Healing of Colon Anastomosis: An Experimental Study in a Rat Model
}

\author{
(1) Uğur Ekici,' (-) Murat Ferhat Ferhatoğlu, ${ }^{2}$ (-) Bülent Çitgez, ${ }^{3}$ (-) Mehmet Uludağ ${ }^{3}$ \\ 'Department of Health Sciences Collage, Istanbul Gelisim University, Istanbul, Turkey \\ ${ }^{2}$ Department of General Surgery, Okan University Faculty of Medicine, Istanbul,Turkey \\ ${ }^{3}$ Department of General Surgery, Health Sciences University, Sisli Etfal Training and Research Hospital, Istanbul, Turkey
}

\begin{abstract}
Objectives: Ankaferd BloodStopper (ABS) is a topical hemostatic agent that modulates the inflammatory response and accelerates wound healing. The aim of this study was to determine the effects of ABS on the colon anastomosis wound healing in a rat model. Methods: Thirty-two Wistar albino rats were divided into four groups as follows: Group A ( $n=8)$, left colonic anastomosis plus ABS treatment (sacrificed on the $3^{\text {rd }}$ day); Group B $(n=8)$ (control), left colonic anastomosis (sacrificed on the $3^{\text {rd }}$ day); $G r o u p ~ C ~(n=8)$, left colonic anastomosis plus ABS treatment (sacrificed on the $7^{\text {th }}$ day); and Group $D(n=8)$ (control), left colonic anastomosis (sacrificed on the $7^{\text {th }}$ day). All rats were sacrificed at the end of the experiment to assess the anastomosis integrity and the presence of perianastomosis abscesses, peritonitis, and adhesions. Additionally, the bursting pressure and hydroxyproline (OH-pyroline) levels were determined, and a histopathologic evaluation of the perianastomosis tissue was conducted.

Results: The mean bursting pressure on Day 7 was significantly higher than that on Day 3 in the ABS group ( $p=0.017$ ). Overall, the bursting pressure was higher in animals treated with ABS than in the control animals, although the difference was not statistically significant. The $\mathrm{OH}$-pyroline levels of both $\mathrm{ABS}$ groups were significantly higher than in the control groups. The mean $\mathrm{OH}$-pyroline level on Day 7 was higher than that on Day 3 in the ABS-treated animals $(p=0.038)$.

Conclusion: ABS increases collagen formation and neovascularization, and it has a positive impact during the colon anastomosis healing in an experimental model of wound healing.

Keywords: Ankaferd BloodStopper; colon anastomosis; wound healing.

Please cite this article as "Ekici U, Ferhatoğlu MF, Çitgez B, Uludağ M. Effects of the Folk Medicinal Plant Extract Ankaferd BloodStopper on the Healing of Colon Anastomosis: An Experimental Study in a Rat Model. Med Bull Sisli Etfal Hosp 2019;53(2):154-159".
\end{abstract}

C olorectal cancer is the fourth most common cause of cancer deaths worldwide, ${ }^{[1]}$ and the anastomosis leakage is one of the most important complications of colorectal surgery. Despite the recent advances in surgical techniques and technologic devices, the anastomosis leakage occurs in up to $37 \%$ of patients with colorectal cancer. ${ }^{[2]}$ The main risk factors of leakage include patient-related factors, such as severe anemia, diabetes mellitus, immunosuppression, history of radiation therapy, sepsis, malnutrition, hypoalbuminemia, and hypovolemia, as well as issues with the surgical techniques including excessive suture tension, inadequate perfusion of the anastomosis edges, distal lu-

Address for correspondence: Murat Ferhat Ferhatoğlu, MD. Okan Universitesi Tip Fakultesi, Genel Cerrahi Anabilim Dali, Istanbul, Turkey Phone: +90 5553214793 E-mail: ferhatferhatoglu@gmail.com

Submitted Date: February 05, 2019 Accepted Date: March 11, 2019 Available Online Date: June 24, 2019

${ }^{\circ}$ Copyright 2019 by The Medical Bulletin of Sisli Etfal Hospital - Available online at www.sislietfaltip.org

OPEN ACCESS This is an open access article under the CC BY-NC license (http://creativecommons.org/licenses/by-nc/4.0/). 
minal obstruction, and abdominal contamination with faucal content. ${ }^{[3]} \mathrm{A}$ tension-free technique and intact blood perfusion guarantee the stability of anastomosis.

Ankaferd BloodStopper (ABS) is a topical hemostatic agent for the management of hemorrhage where conventional methods to stop hemorrhage are ineffective. ${ }^{[4]} A B S$ contains extracts from five different plants (Thymus vulgaris, $5 \mathrm{mg} / 100 \mathrm{ml}$; Glycyrrhiza glabra, $9 \mathrm{mg} / 100 \mathrm{ml}$; Vitisvinifera, $8 \mathrm{mg} / 100 \mathrm{ml}$; Alpiniaofficinarum, $7 \mathrm{mg} / 100 \mathrm{ml}$; and Urtica dioica, $6 \mathrm{mg} / 100 \mathrm{ml}$ ). ABS modulates the inflammatory response via its effects on endothelium, neovascularization, and cytokines. ${ }^{[4-6]} \mathrm{ABS}$ also accelerates wound healing by increasing the cellular and vascular proliferation,,$^{[7]}$ and healing of colonic anastomoses depends on these proliferative processes. In this study on an experimental rat model, we aimed to evaluate the efficacy of ABS on wound healing in colon anastomosis.

\section{Methods}

Thirty-two female Wistar albino rats with the mean weight of $235 \mathrm{~g}$ (200-275 g) obtained from the Laboratory of Experimental Animals at Biological Experiments with Living Animals laboratory of Istanbul University, Istanbul, Turkey were used in this study. The rats were provided with a regular laboratory rat diet and tap water with a 12-hour day/ night light cycle at room temperature of $24^{\circ} \mathrm{C}-26^{\circ} \mathrm{C}$. Four groups containing 8 rats each were formed. The rats were housed 2/per cage and were allowed to move freely.

Randomization of the rats into groups was achieved using computer-generated random numbers. None of the animals died during the study. The study design and all procedures were approved by the Ethics Committee of the Experimental Medicine Research Institute at Istanbul University.

For the study, there were four groups formed as follows: Group $A(n=8)$, left colonic anastomosis plus ABS treatment (sacrificed on the $3^{\text {rd }}$ day); Group $B(n=8)$ (control), left colonic anastomosis (sacrificed on the $3^{\text {rd }}$ day); Group $C(n=8)$, left colonic anastomosis plus ABS treatment (sacrificed on the $7^{\text {th }}$ day); and Group $D(n=8)$ (control), left colonic anastomosis (sacrificed on the $7^{\text {th }}$ day).

All rats were sacrificed to assess the anastomosis integrity, and the presence of perianastomosis abscesses, peritonitis, and adhesions. In addition, the bursting pressure and hydroxyproline ( $\mathrm{OH}$-proline) levels were determined, and the histopathologic evaluation of the perianastomosis tissue was performed.

\section{Surgical Procedure}

All rats were fasted for 8 hours before surgery, which was performed under sterile conditions. All colon anastomoses were performed by the same uninformed/blind surgeon, using six sutures. General anesthesia was administered with $50 \mathrm{mg} / \mathrm{kg}$ ketaminehydrochloride intraperitoneally and $5 \mathrm{mg} / \mathrm{kg}$ xylazinehydrochloride intramuscularly. Next, the anterior abdominal wall was shaved with an electric razor and wiped with povidone iodine to obtain antiseptic conditions (Fig. 1). The peritoneal cavity was exposed with a $4 \mathrm{~cm}$ midline abdominal incision. The left colon was mobilized, and a full-layer cut was created in a $90^{\circ}$ angle to the longitudinal axis of the colon. After the exploration of the abdominal cavity, animals with gastrointestinal anomalies and intra-abdominal tumors were excluded from the study. Next, end-to-end colocolic anastomosis was performed using a nonabsorbable mono filament $6 / 0$ polypropylene inverting sutures (Fig. 2), and 0.1 CC of ABS was wiped on the anastomosis line. The abdominal wall was closed with $3 / 0$ silk sutures (Fig. 3). At the end of the procedure, $15 \mathrm{ml}$ of sterile saline was injected subcutaneously for postoper-

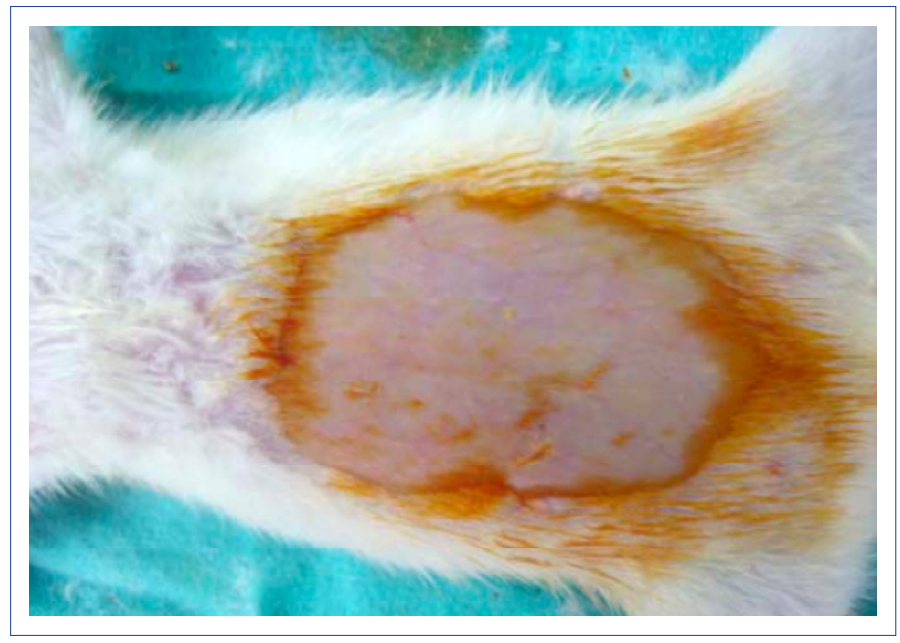

Figure 1. Shaved and cleansed abdominal wall.

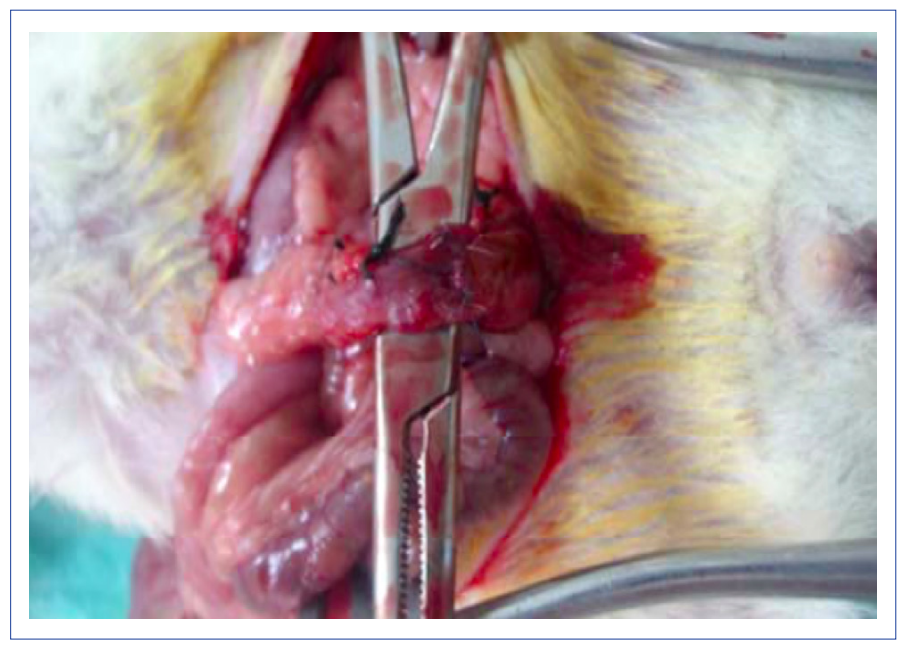

Figure 2. Completed anastomosis. 


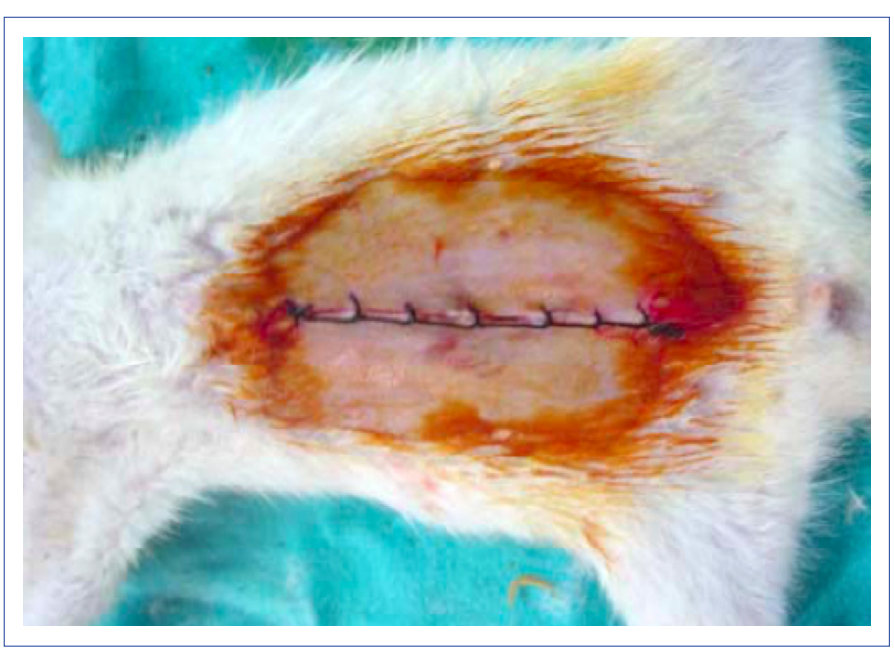

Figure 3. Closed skin of the rat.

ative hydration. Animals were fasted for postoperative 24 hours, after which they were started on standard diet and drinking water.

\section{Evaluation of Adhesions}

The uninformed/blind surgeon made the postmortem examination that was conducted to grade adhesions on a scale from 0 to 3 according to the method introduced by van Deer Ham et al. ${ }^{[7]}$ (Table 1).

\section{Measurement of Colonic Anastomosis Bursting Pressure}

The uninformed/blind surgeon made the bursting pressure measurements, which were obtained within 3 minutes of sacrifice. First, the anastomosis integrity was determined by exposing the anastomosis line and removal of the adhesions in the surrounding tissues. Next, two cuts, one $2 \mathrm{~cm}$ proximal and the other $2 \mathrm{~cm}$ distal to the anastomosis site, were made to obtain a 4-cm-long colonic segment. Faucal content of the colon was removed with physiologic saline solution. The distal end of the excised segment was ligated using 4/0 silk sutures after an infusion set connected to a sphygmomanometer was inserted into the proximal end of the colon segment. The resected colon segment was then placed in a beaker filled with physiological saline solution

Table 1. Adhesion grading scale

\footnotetext{
0 : No adhesions

1: Minimal adhesions, mainly between the omentum and the anastomosis site

2: Moderate adhesions, i.e., between the anastomosis site and the omentum or between the anastomosis site and a loop of the small bowel or the abdominal wall

3: Severe and extensive adhesions, i.e., between the anastomotic site and several loops of the small bowel and the abdominal wall, including the abscess formation
}

and inflated with air. The intraluminal pressure was increased in $10 \mathrm{mmHg}$ increments and maintained for $10 \mathrm{sec}-$ onds. The appearance of air bubbles was used to record the bursting pressure in $\mathrm{mmHg}$. Notably, bursting occurred at the anastomosis line in all samples. The bursting pressure of rats with the anastomosis leakage was determined as 0 $\mathrm{mmHg}$; these animals were excluded from the study. Next, the anastomosis segment was cut across the longitudinal axis and divided into two half rings; one half was placed in $10 \%$ formalin solution for histopathological evaluation, and the other half was stored at $-80^{\circ} \mathrm{C}$ for the $\mathrm{OH}$-proline measurement.

\section{Histopathological Evaluation}

The formalin-fixed colonic segments were sectioned, stained with hematoxylin and eosin, and analyzed with light microscopy at the 200x magnification by the same pathologist who was blinded to the treatment groups. The infiltration of inflammatory cells (leukocyte count), activity of fibroblast cells, neoangiogenesis, and collagen content were measured using the modified Ehrlich and Hunt scale by Philips et al. ${ }^{[8]}$

\section{Tissue OH-Proline Assay}

The tissue concentrations of $\mathrm{OH}$-proline, which represent perianastomosis collagen levels, were measured using the spectrophotometric method by Bergman and Loxley. [9] The values were expressed as the microgram amount of $\mathrm{OH}$-proline per milligram of tissue $(\mu \mathrm{g} / \mathrm{mg})$.

\section{Statistical Analysis}

Descriptive statistics including the frequency distribution and the mean and standard deviation were used. The Kruskal-Wallis variance analysis was used to determine intergroup differences; paired groups were compared using the Mann-Whitney $U$ test for analyses yielding significant results. P-values less than 0.05 were considered statistically significant. The Statistical Package for Social Sciences for Windows 11.0 was used for all statistical analyses.

\section{Results}

A statistically difference with regard to the anastomosis dehiscence and intra-abdominal abscess was not observed between the groups (Table 2).

Comparison of the tested variables between the $A B S$ (Groups A-C) and control (Groups B-D) groups are shown in Table 3, 4. Acute inflammation, fibroblast activation, and neovascularization scores did not significantly differ between the groups. However, collagenization scores were significantly higher on both Days 3 and 7 after surgery in the $A B S$ group. 
Table 2. Evaluation of anastomosis dehiscence, intra-abdominal abscess, intestinal obstruction, adhesion score

\begin{tabular}{|c|c|c|c|}
\hline & $\begin{array}{c}\text { Control } \\
\text { group } \\
\text { n (\%) }\end{array}$ & $\begin{array}{l}\text { ABS } \\
\text { group } \\
\text { n (\%) }\end{array}$ & $\mathbf{p}$ \\
\hline \multicolumn{4}{|c|}{ Anastomoses dehiscence } \\
\hline \multicolumn{4}{|c|}{$3^{\text {rd }}$ day } \\
\hline No & $7(100)$ & $7(87.5)$ & ${ }^{c} 1.000$ \\
\hline Yes & $0(0)$ & $1(12.5)$ & \\
\hline \multicolumn{4}{|l|}{$7^{\text {th }}$ day } \\
\hline No & $8(100)$ & $8(100)$ & ${ }^{\mathrm{c}} 1.000$ \\
\hline Yes & $0(0)$ & $0(0)$ & \\
\hline${ }^{d} p$ & 0.192 & 0.462 & \\
\hline \multicolumn{4}{|c|}{ Intra-abdominal abscess } \\
\hline \multicolumn{4}{|c|}{$3^{\text {rd day }}$} \\
\hline No & $6(85.8)$ & $6(87.5)$ & ${ }^{c} 1.000$ \\
\hline Yes & $1(14.2)$ & $1(12.5)$ & \\
\hline \multicolumn{4}{|l|}{$7^{\text {th }}$ day } \\
\hline No & $8(100)$ & $7(87.5)$ & ${ }^{c} 1.000$ \\
\hline Yes & $0(0)$ & $1(12.5)$ & \\
\hline${ }^{d} p$ & 0.462 & 1.000 & \\
\hline
\end{tabular}

${ }^{a}$ Kruskal Wallis Test; ${ }^{b}$ Mann Whitney U Test; ${ }^{*} \mathrm{p}<0.05$; ${ }^{\text {CFisher-Freeman-Halton }}$ Exact Test; ${ }^{\text {} F i s h e r ' s ~ E x a c t ~ T e s t . ~}$

Table 3. The comparison between $A B S$ and control group via histopathological analysis in day3

\begin{tabular}{lccc}
\hline Variable & $\begin{array}{c}\text { ABS } \\
\text { (Day 3) } \\
\text { (mean } \pm \text { SD) }\end{array}$ & $\begin{array}{c}\text { Control } \\
\text { (Day 3) } \\
\text { (mean } \pm \text { SD) }\end{array}$ & p \\
\hline Acute inflammation* & $3.5 \pm 1.06$ & $3.37 \pm 0.51$ & ${ }^{\mathrm{a}} 0.256$ \\
Fibroblast activation* & $2.5 \pm 0.75$ & $2.25 \pm 0.46$ & ${ }^{\mathrm{a}} 0.289$ \\
Collagen* $_{\text {Neovascularization* }}$ & $2.87 \pm 0.35$ & $2.37 \pm 0.51$ & ${ }^{\mathrm{a}} 0.046$ \\
\hline
\end{tabular}

*Ehrlich and Hunt scale score. ${ }^{a}$ Kruskal-Wallis Test; SD: Standard Deviation.

Table 4. The comparison between ABS and control group via histopathological analysis in day 7

\begin{tabular}{lccc}
\hline Variable & $\begin{array}{c}\text { ABS } \\
\text { (Day 7) } \\
\text { (mean } \pm \text { SD) }\end{array}$ & $\begin{array}{c}\text { Control } \\
\text { (Day 7) } \\
\text { (mean } \pm \text { SD) }\end{array}$ & p \\
\hline Acute inflammation* & $3.5 \pm 0.53$ & $3.75 \pm 0.46$ & ${ }^{\mathrm{a}} 0.317$ \\
Fibroblast activation* & $3.12 \pm 0.64$ & $2.75 \pm 0.46$ & ${ }^{\mathrm{a}} 0.199$ \\
Collagen* $^{*}$ & $3.37 \pm 1.06$ & $2.75 \pm 0.46$ & ${ }^{\mathrm{a}} 0.040$ \\
Neovascularization* $^{*}$ & $2.87 \pm 0.35$ & $2.62 \pm 0.51$ & ${ }^{\mathrm{a}} 0.264$ \\
\hline
\end{tabular}

*Ehrlich and Hunt scale score; ${ }^{a}$ Kruskal-Wallis Test; SD: Standard Deviation.

The mean values of the bursting pressure, adhesion score, and $\mathrm{OH}$-proline level are presented in Tables 5, 6, and 7, respectively. The bursting pressure of one rat from the control group on Day 3 was determined as $0 \mathrm{mmHg}$, and it was excluded from the study. In addition, briefly, the mean
Table 5. The comparison between ABS and control group via bursting pressure, adhesion score, $\mathrm{OH}$-pyroline level in day 3

\begin{tabular}{lccc}
\hline Variable & $\begin{array}{c}\text { ABS } \\
\text { (Day 3) } \\
\text { (mean } \pm \text { SD) }\end{array}$ & $\begin{array}{c}\text { Control } \\
\text { (Day 3) }\end{array}$ & p \\
(mean \pm SD) & \\
\hline Bursting pressure $(\mathrm{mmHg})$ & $91.25 \pm 39.07$ & $61.25 \pm 9.9$ & ${ }^{\mathrm{b}} 0.66$ \\
Adhesion scoret & $1.5 \pm 0.53$ & $1.62 \pm 0.51$ & ${ }^{\mathrm{b}} 1.00$ \\
OH-pyroline $(\mu \mathrm{g} / \mathrm{mg})$ & $564.62 \pm 59.93$ & $369.5 \pm 51.53$ & ${ }^{\mathrm{b}} 0.001$ \\
\hline
\end{tabular}

†Adhesions were graded according to system developed by van Der Ham et al. ' ${ }^{b}$ Mann Whitney U Test; SD: Standard Deviation.

Table 6. The comparison between ABS and control group via bursting pressure, adhesion score, $\mathrm{OH}$-pyroline level in day 7

\begin{tabular}{lccc}
\hline Variable & $\begin{array}{c}\text { ABS } \\
\text { (Day 7) } \\
\text { (mean } \pm \text { SD) }\end{array}$ & $\begin{array}{c}\text { Control } \\
\text { (Day 7) } \\
\text { (mean } \pm \text { SD) }\end{array}$ & p \\
\hline Bursting pressure $(\mathrm{mmHg})$ & $193 \pm 28.75$ & $165 \pm 53.45$ & ${ }^{\mathrm{b}} 0.34$ \\
Adhesion scoret & $1.87 \pm 0.35$ & $2.12 \pm 0.35$ & ${ }^{\mathrm{b}} 0.31$ \\
OH-pyroline $(\mu \mathrm{g} / \mathrm{mg})$ & $614.12 \pm 81.68$ & $457.25 \pm 85.35$ & ${ }^{\mathrm{b}} 0.007$ \\
\hline
\end{tabular}

† Adhesions were graded according to system developed by van Der Ham et al. ${ }^{b}$ Mann Whitney U Test; SD: Standard Deviation.

Table 7. The comparison between ABS day 3 and ABS day 7 group via bursting pressure, adhesion score, $\mathrm{OH}$-pyroline level

\begin{tabular}{lccc}
\hline Variable & $\begin{array}{c}\text { ABS } \\
\text { (Day 3) } \\
\text { (mean } \pm \text { SD) }\end{array}$ & $\begin{array}{c}\text { ABS } \\
\text { (Day 7) } \\
\text { (mean } \pm \text { SD) }\end{array}$ & p \\
\hline Bursting pressure $(\mathrm{mmHg})$ & $91.25 \pm 39.07$ & $193 \pm 28.75$ & ${ }^{\mathrm{b}} 0.017$ \\
Adhesion scoret & $1.5 \pm 0.53$ & $1.87 \pm 0.35$ & ${ }^{\mathrm{b}} 0.63$ \\
OH-pyroline $(\mu \mathrm{g} / \mathrm{mg})$ & $564.62 \pm 59.93$ & $614.12 \pm 81.68$ & ${ }^{\mathrm{b}} 0.038$ \\
\hline
\end{tabular}

† Adhesions were graded according to system developed by van Der Ham

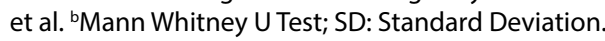

bursting pressure on Day 3 was significantly higher than that on Day 7 in the ABS group ( $p=0.017$ ) (Table 7). Overall, the bursting pressure was higher in animals treated with ABS than the control animals, although the difference was not statistically significant.

The $\mathrm{OH}$-proline levels of both ABS groups were significantly higher than control groups. The mean $\mathrm{OH}$-proline level on Day 7 was higher than that on Day 3 in the ABS-treated animals $(p=0.038)$.

\section{Discussion}

Anastomotic leakage remains a challenge associated with morbidity and mortality in patients undergoing colorectal surgery. Leakage at the site of anastomosis was also reported to contribute to an increase in the length of hospital stays and medical costs. ${ }^{[10-12]}$ Treatment of anastomosis leakage is difficult and may require re-laparotomy, with fre- 
quent necessity of stoma formation. Therefore, the prevention of anastomosis leakage remains the most critical issue. However, nonmodifiable risk factors such as an advanced age, comorbid conditions, and emergency surgery hinder these efforts, ${ }^{[3]}$ highlighting the need for new treatment strategies to prevent anastomosis leakage. To this end, numerous experimental and clinical studies were conducted to achieve better wound healing after colon anastomosis. ${ }^{[3,12-14]}$

Numerous studies have demonstrated the hemostatic effect of $A B S$, which shortens the bleeding time and the amount of blood loss. ${ }^{[4-6,17]}$ The main mechanism underlying this effect of $A B S$ is an encapsulated protein network formation and increased erythrocyte aggregation. ${ }^{[15]}$ Additionally, ABS increases vascular proliferation by reducing tissue necrosis. [16] Several studies have also shown the anti-inflammatory effects of $A B S .[4-7,16,17]$ Interleukins are common to both the inflammatory/anti-inflammatory and the coagulation cascades that are targeted by ABS. ${ }^{[3]}$ The most important factor in anastomotic healing is collagen, which forms the tensile strength of submucosal connective tissue. ${ }^{[18]}$ Increased inflammation may cause excessive collagenolysis, and the anti-inflammatory function of ABS might inhibit collagenolysis during tissue healing ${ }^{\left[{ }^{[15]}\right.} \mathrm{OH}$-proline levels can be used to assess collagen formation during wound healing. $\mathrm{OH}$-proline is a component of collagen, which was shown to be positively correlated with the collagen amount and strength of anastomosis. ${ }^{[19]}$ In the current study, the $\mathrm{OH}$-proline levels were significantly higher in the ABS-treated animals; furthermore, the $\mathrm{OH}$-proline levels were higher on Day 7 compared to those on Day 3 among the animals treated with ABS. These results suggest that $A B S$ might increase the strength of anastomosis by inducing collagen formation. ABS might also decrease collagenolysis via an anti-inflammatory action, which requires further studies.

In clinical practice, the physical strength of anastomosis is not an ideal parameter to assess the healing of colonic anastomosis; ${ }^{[20]}$ nonetheless, bursting pressure was used as an indirect method to assess the anastomotic integrity. We found that bursting pressure of the animals treated with ABS is higher than control groups, whereas there was no significant difference in the bursting pressures between the ABS-treated and the control groups.

Fibroblasts and neovascularization promote synthesis of collagen and mucopolysaccharides to increase anastomotic strength. ${ }^{[21]}$ The first endothelial cells are seen 48 hours after the beginning of inflammatory process, and this inflammatory process ends on the 6th or $7^{\text {th }}$ day. ${ }^{[22]}$ The fibrinopurulent exudate fills anastomotic space in peritoneal sepsis. This exudate reduces the collagen synthesis and formation of new blood vessels and, as a result, anastomo- sis heals by secondary intention. ${ }^{[23]}$ In the presented study, fibroblast activity and neoangiogenesis were not statistically different between the control and ABS groups. We believe that the anti-inflammatory and antioxidant activity of ABS promotes the endothelial cell activity.

There was no difference in neovascularization and fibroblast activity and indicators of fibroblast activity between the ABS and the control groups in the current study. However, histopathological evaluation might not be ideal to assess overlooked ultrastructural changes, and an evaluation by electron microscopy may provide more information on fibrosis and neovascularization. In addition, the short duration of observation in the current study might not have allowed for ultrastructural changes to become evident. Future studies with a longer treatment time that utilize more advanced techniques such as electron microscopy should allow for a better assessment of ultrastructural changes.

The current study findings did not reveal a clear clinical application for $A B S$ in increasing the strength and safety of anastomosis; however, based on our finding of ABS-mediated increase in collagenization. In accordance with the study by Cancan et al. ${ }^{[19]}$ which investigated the same issue regarding $A B S$, we also revealed that $A B S$ has a positive impact in the healing of colonic anastomosis performed under optimal surgical conditions, but further studies are required to elucidate the role of $A B S$ in anastomotic healing under septic conditions.

\section{Conclusion}

ABS increases the collagen formation and neovascularization, and it has a positive impact on the colon anastomosis healing in an experimental rat model of wound healing. Thus, ABS promotes colonic healing and provides a safer and stronger anastomosis than suturing alone.

Although further studies are needed to define the mechanism of the $A B S$ impact in the anastomotic healing of colon, our results are promising for clinical use of $A B S$ to improve the safety of colonic anastomoses.

\section{Disclosures}

Ethics Committee Approval: This study was approved by the Biological Experiments with Living Animals Ethic Committe of Istanbul University, Istanbul, Turkey.

Peer-review: Externally peer-reviewed.

Conflict of Interest: None declared.

Authorship Contributions: Concept - U.E.; Design - U.E., B.C.; Supervision - M.U.; Materials - U.E.; Data collection \&/or processing - U.E.; Analysis and/or interpretation - U.E., M.F.F.; Writing U.E., M.F.F.; Critical review - B.C., M.U. 


\section{References}

1. Bhandari A, Woodhouse M, Gupta S. Colorectal cancer is a leading cause of cancer incidence and mortality among adults younger than 50 years in the USA: a SEER-based analysis with comparison to other young-onset cancers. J Investig Med 2017;65:311-5. [CrossRef]

2. Neumann PA, Twardy V, Becker F, Geyer C, Schwegmann K, Mohr $A$, et al. Assessment of MMP-2/-9 expression by fluorescence endoscopy for evaluation of anastomotic healing in a murine model of anastomotic leakage. PLoS One 2018;13:e0194249.

3. Akyuz C, Yasar NF, Uzun O, Peker KD, Sunamak O, Duman M, et al. Effects of melatonin on colonic anastomosis healing following chemotherapy in rats. Singapore Med J 2018;59:545-9. [CrossRef]

4. Haznedaroglu BZ, Beyazit Y, Walker SL, Haznedaroglu IC. Pleiotropic cellular, hemostatic, and biological actions of Ankaferd hemostat. Crit Rev Oncol Hematol 2012;83:21-34. [CrossRef]

5. Goker H, Haznedaroglu IC, Ercetin S, Kirazli S, Akman U, Ozturk Y, et al. Haemostatic actions of the folkloric medicinal plant extract Ankaferd Blood Stopper. J Int Med Res 2008;36:163-70. [CrossRef]

6. Işler SC, Demircan S, Cakarer S, Cebi Z, Keskin C, Soluk M, et al. Effects of folk medicinal plant extract Ankaferd Blood Stopper on early bone healing. J Appl Oral Sci 2010;18:409-14. [CrossRef]

7. van der Ham AC, Kort WJ, Weijma IM, van den Ingh HF, Jeekel H. Effect of antibiotics in fibrin sealant on healing colonic anastomoses in the rat. Br J Surg 1992;79:525-8. [CrossRef]

8. Phillips JD, Kim CS, Fonkalsrud EW, Zeng H, Dindar H. Effects of chronic corticosteroids and vitamin A on the healing of intestinal anastomoses. Am J Surg 1992;163:71-7. [CrossRef]

9. Bergman I, Loxley R. Two improved and simplified methods for the spectrophotometric determination of hydroxyproline. Ann Chem 1963;35:1961-5. [CrossRef]

10. Daglioglu YK, Duzgun O, Sarici IS, Ulutas KT. Comparison of platelet rich plasma versus fibrin glue on colonic anastomoses in rats. Acta Cir Bras 2018;33:333-40. [CrossRef]

11. Ersoz N, Ozler M, Topal T, Uysal BZ, Poyrazoglu Y, Simsek K, et al. The effect of ozone treatment on experimental colon anastomosis in rats. Eur Surg 2016;48:122-8. [CrossRef]

12. Strunden MS, Heckel K, Goetz AE, Reuter DA. Perioperative fluid and volume management: physiological basis, tools and strategies. Ann Intensive Care 2011;1:2. [CrossRef]
13. Bai J, Huo X, Ma J, Lv Y, Yan X. Magnetic compression technique for colonic anastomosis in rats. J Surg Res 2018;231:24-9. [CrossRef]

14. Trotter J, Onos L, McNaught C, Peter M, Gatt M, Maude K, et al. The use of a novel adhesive tissue patch as an aid to anastomotic healing. Ann R Coll Surg Engl 2018;100:230-4. [CrossRef]

15. Aydın BK, Altan E, Acar MA, Erkoçak ÖF, Ugraş S. Effect of Ankaferd blood stopper ${ }^{\circledR}$ on tendon healing: an experimental study in a rat model of Achilles tendon injury. Eklem Hastalik Cerrahisi 2015;26:31-7. [CrossRef]

16. Akbal E, Köklü S, Karaca G, Astarci HM, Koçak E, Taş A, et al. Beneficial effects of Ankaferd Blood Stopper on caustic esophageal injuries: an experimental model. Dis Esophagus 2012;25:188-94.

17. Ozel-Demiralp D, Igci N, Ayhan B, Egin Y, Haznedaroglu IC, Akar $\mathrm{N}$. Prohemostatic and antithrombin activities of Ankaferd hemostat are linked to fibrinogen gamma chain and prothrombin by functional proteomic analyses. Clin Appl Thromb Hemost 2012;18:604-10. [CrossRef]

18. Adam AB, Özdamar MY, Esen HH, Günel E. Local effects of epidermal growth factor on the wound healing in esophageal anastomosis: An experimental study. Int J Pediatr Otorhinolaryngol 2017;99:8-12. [CrossRef]

19. Cancan G, Teksoz S, Aytac E, Arikan AE, Erman H, Uzun H, et al. Effects of Ankaferd on anastomotic healing of colon. J Invest Surg 2014;27:1-6. [CrossRef]

20. Subhas G, Bhullar JS, Cook J, Shah A, Silberberg B, Andrus L, et al. Topical gentamicin does not provide any additional anastomotic strength when combined with fibrin glue. sAm J Surg 2011;201:339-43. [CrossRef]

21. Mariggiò MA, Cassano A, Vinella A, Vincenti A, Fumarulo R, Lo Muzio $L$, et al. Enhancement of fibroblast proliferation, collagen biosynthesis and production of growth factors as a result of combining sodium hyaluronate and aminoacids. Int J Immunopathol Pharmacol 2009;22:485-92. [CrossRef]

22. Oguido APMT, Hohmann MSN, Pinho-Ribeiro FA, Crespigio J, Domiciano TP, Verri WA Jr, et al. Naringenin Eye Drops Inhibit Corneal Neovascularization by Anti-Inflammatory and Antioxidant Mechanisms. Invest Ophthalmol Vis Sci 2017;58:5764-76. [CrossRef]

23. Saravanan M. A Comperative Study Between Single Versus Double Layered Intestinal Anastomosis. [Thesis]. The Tamil Nadu Dr. M.G.R. Medical University, India. 2015. 